\title{
Challenges in Prosecuting Sexual Violence in Armed Conflict under Nigerian Law
}

\author{
Theresa U. Akpoghome1, Ufuoma V. Awhefeada ${ }^{2 *}$ \\ ${ }^{1}$ Faculty of Law, Benson Idahosa University, Benin, Nigeria \\ ${ }^{2}$ Faculty of Law, Delta State University, Abraka, Nigeria \\ Email: teremajor@gmail.com, ^fuoma2002@yahoo.com
}

How to cite this paper: Akpoghome, T. U., \& Awhefeada, U. V. (2020). Challenges in Prosecuting Sexual Violence in Armed Conflict under Nigerian Law. Beijing Law Review, 11, 262-276. https://doi.org/10.4236/blr.2020.111018

Received: February 12, 2020

Accepted: March 20, 2020

Published: March 23, 2020

Copyright $\odot 2020$ by author(s) and Scientific Research Publishing Inc. This work is licensed under the Creative Commons Attribution International License (CC BY 4.0).

http://creativecommons.org/licenses/by/4.0/ (c) (i) Open Access

\begin{abstract}
In the past decade, Nigeria has experienced an increased rate of sexual violence in armed conflict between the armed forces of the State and the dissident armed group, Boko Haram. This paper carefully examines the challenges of prosecuting sexual violence in armed conflict under the Nigerian law. The paper extensively analyzes sexual violence in the context of non international armed conflict. It traces the history of sexual violence in armed conflicts in Nigeria. The paper reaffirms the point that sexual violence in times of armed conflict constitutes an international crime. It contends that the inability to prosecute is based on some factors which include the lack of relevant laws to address the crime as well as the absence of domestication of international treaties in this regard as a major constraint to prosecution. It is argued therefore that this creates a gap in terms of protection afforded victims as well as accountability of perpetrators. The paper concludes by recommending that all laws prohibiting sexual violence which have been ratified should be domesticated in order to have the platform upon which accountability will stand.
\end{abstract}

\section{Keywords}

Sexual Violence, Domestication, Prosecution, Accountability, Rome Statute

\section{Introduction}

This paper examines the challenges in prosecuting sexual violence in armed conflict under Nigerian law. This is with a view to establishing the extent of protection and accountability afforded by the Nigerian law both to the victims and the perpetrators of sexual violence. Sexual violence in armed conflict is not a new trend. All through history reports abound which shows that rape is considered by members of armed groups be it State military or non-State actors as the legi- 
timate spoils of war and this to an extent made sexual violence acceptable throughout the early part of twentieth century (Bigro \& Vogelstein 2017).

In recent times, there is a plethora of authorities as contained in articles 6, 7, 8 of the Rome Statute of the International Criminal Court (ICC) recognizing sexual violence in armed conflict as genocide, war crime or crime against humanity (Rome Statute of the International Criminal Court (ICC), 1998). With the United Nations Security Council declaring the massive, organized and systematic detention of women in the former Yugoslavia in 1992 as international crime, there is now a more robust adjudication of sexual violence in armed conflict all over the world.

In 2017, the United Nations identified forty six parties to ten conflicts as credibly suggested of committing rape and other forms of sexual violence (Bigro \& Vogelstein 2017). Seven of the groups were identified as terrorist groups because of their links with Islamic State and Al Qaeda (Ibid). This is not to say that all armed groups rape women. However, sexual violence in times of armed conflict can take different forms. Armed groups and individuals commit sexual offences in times of conflict for a number or combination of reasons which may include but not limited to the use of rape as a deliberate tactics or method of war, an act of opportunism, a type of troop payment, and an effort to solidify the cohesion of the armed group or an instrument for ethnic destruction.

It is important to note that sexual violence in times of armed conflict can violate national criminal law, international law and can be as noted earlier a war crime, crime against humanity and genocide. It is in the light of the above that the paper seeks to discover the challenges in prosecuting sexual violence in armed conflict in Nigeria. In view of this, this paper presents a brief definition of sexual violence in armed conflict, discusses the concept of armed conflict albeit briefly, undertakes a brief historical overview of sexual violence in Nigeria's armed conflict situation, looks at the challenges of prosecuting these crimes in Nigeria and presents some recommendations and conclusions.

\section{Definition of Armed Conflict}

Armed conflict has been categorized into two broad classifications- international armed conflict (IAC) and non-international armed conflict (NIAC). The discussion on the definition of IAC is beyond the scope of this paper therefore, the definition will be limited to NIAC.

Article 1(1) Additional Protocol II to the Geneva Conventions defines a non-international armed conflict thus:

All armed conflicts... and which take place in the territory of a High Contracting Party between its armed forces and dissident armed forces or other organized armed groups which, under a responsible command, exercise such control over a part of its territory as to enable them to carry out sustained and concerted military operation ... 
From the above it can be inferred that there is a state of armed conflict in $\mathrm{Ni}$ geria between the Nigerian armed forces and the Boko Haram group that have occupied some territories in Nigeria and have been able to carry out sustained and concerted military operations. This type of armed violence does not admit of sporadic attacks or acts of banditry which do not qualify as armed conflict thereby excluding the application of the rules of IHL. Therefore, the violence must be intense and meet the required threshold for its qualification as an armed conflict. When the insurgency began, it was considered as 'Other Situations of Violence' (OSV) due to its nature but as time progressed the violence met the required threshold calling for the use of the armed forces of the Federation to counter the attacks.

Aside the definition provided for in the Protocol II, the ICTY Appeal Chambers in Tadic case gave a comprehensive and authoritative definition of armed conflict when it stated that: “... an armed conflict exists whenever; there is a resort to armed force between States or protracted armed violence between government authorities and organized armed groups or between such groups within the State" (Prosecutor v. Dusko Tadic 1995).

On the application of international humanitarian law, the tribunal further posits that:

International humanitarian law applies from the initiation of such armed conflict and extends beyond the cessation of hostilities until a general conclusion of peace is reached, or in the case of internal conflicts, a peaceful settlement is achieved. Until that moment International Humanitarian Law continues to apply in the territory of the warring State or in the case of internal conflicts, the whole territory under the control of a party, whether or not actual combat takes place there.

In other words, IHL will not apply in times of 'other situations of violence' which do not qualify as armed conflicts. Going by the definitions of armed conflict from both the Protocol and ICTY, the situation in the Northeast of Nigeria has met the qualifications as noted above; therefore where international crimes have been committed the question of accountability from the actors becomes imperative. The next section of this paper examines the conflict in Nigeria and whether sexual violence has been committed in the conflict.

\section{Sexual Violence in Armed Conflict}

Sexual violence is any act of sexual intimacy or gratification obtained without the consent of the victim; in this context, in times of armed conflict. Sexual violence which happens in time of armed conflict is linked to the conflict in the sense that the conflict influenced the perpetrators' decision or his ability to commit the crime. Sexual violence can be made up of other categories of crime. These include for example genocide, torture, persecution, enslavement, inhumane acts as crimes against humanity or cruel treatment, inhumane treatment, 
outrages upon personal dignity and slavery as war crimes. The 2017 Annual Report of the Secretary General on conflict related sexual violence posits that this involves rape, sexual slavery, forced prostitution, forced pregnancy, forced abortion, enforced sterilization, forced marriage and any other form of sexual violence of comparable gravity against women, men girls, boys that is directly or indirectly linked to the conflict.

The International Criminal Tribunal for Rwanda (ICTR, 1994) Trial Chamber held that sexual violence could fall within the scope of inhumane acts, outrages upon personal dignity and serious bodily or mental harm, thereby violating common Article 3 to the four Geneva Conventions as evidenced in ICTR, Prosecutor v. Jean Paul Akeyesu, Case No. ICTR-96-4. The Trial Chamber also noted that sexual violence could constitute genocide when committed with the intent to destroy in part a national, ethnic, racial or religious groups (ICTR 1997).

The International Criminal Tribunal for the former Yugoslavia (ICTY) in Prosecutor v. Dragoljub Kunarac and Others recognized that sexual violence could constitute on outrage upon personal dignity, as well as enslavement and torture (ICTY, 2001). The ICTY again in ICTY Prosecutor v. Tadic held that male sexual assault, including mutilation, fellatio and indecent assault constituted inhumane treatment, cruel treatment as war crimes and inhuman acts as crimes against humanity (ICTR 1997).

The Appeal Chamber of the Special Court for Sierra Leone (2002) in Prosecutor v. Alex Tamba Brima, Brima Bazzy Kamera, Santigie Birbor Kanu also recognized that the abduction of women by members of the armed forces to turn them into "bush wives" constituted a crime against humanity and amounts to an act of terror which is expressly prohibited by International Humanitarian Law (SC-SL 2007). The Rome Statute recognizes as war crimes any other forms of sexual violence that constitute a grave breach of the Geneva Conventions of 1949 or a serious violation of common Article 3 as exemplified under Article 8(2) (e) (vi) Rome Statute of the ICC.

A careful examination of Common Article 3 would reveal that rape and other forms of sexual violence were not mentioned among the crimes that can be prosecuted if committed in a non-international armed conflict, but it would not be an inhibition for courts to consider sexual violence as war crime in non-international armed conflicts.

Invariably, the offence of sexual violence as noted by the International Criminal Court (ICC) and other courts would function as a 'residual clause' which potentially prohibit sexual assault conduct, such as sexual mutilation, that is not specifically listed as crime, but that is of comparable gravity which would permit the courts to exercise jurisdiction over any other serious sexual assault of equal gravity to the mentioned sexual based crimes in both international and non-international armed conflicts (University of Oslo). This umbrella phrase inevitably covers all serious sexually abusive conduct which would include rape, trafficking or slavery. In the same vein, sexual mutilation could constitute sexual 
assault. This means that the threshold of gravity to constitute a crime remains open creating room for jurisprudential interpretation (Ibid).

From the above analysis, it could be concluded that sexual violence can be a crime against humanity where it is wide spread and systematic and directed against protected persons as contained under Article 7 ICC Statute of the ICC. Under Articles 6, 7, 8 of the Rome Statute of the ICC; it could be a war crime if it can be linked to the armed conflict and genocide if it is directed against a nationality, tribe or religion with the intent to destroy in whole or in part any such group. Again, sexual violence in armed conflict involves boys, men, women, girls but women and girls are particularly discussed due to their vulnerable nature. Finally, on this point sexual violence includes abduction of girls/women which is prevalent in the north east of Nigeria and it will be important to observe at this point that sexual violence in armed conflict often has no bearing to sexual desire, but instead is linked to power, dominance and abuse of authority (Gaggioli, 2014).

\section{Overview of Sexual Violence in Nigeria Conflict}

The Boko Haram group which has been linked to sexual violence in Nigeria had been conducting its affairs peacefully until the tragic extra-judicial killing of their leader, Mohammed Yusuf, in 2009. This event made the group to resort to violence. The insurgents' reign of terror reached its climax when on April 14 2014 they abducted about 276 young school girls in Chibok from their school hostels. This bold attempt by the group generated international reactions largely due to the number and age of the girls involved. The incident in Chibok is not the only case of sexual violence by the group. Amnesty international reported that an estimated 2000 women and girls have been captured and forced into slavery by Boko Haram fighters in a little over 12 months (Batchelor, 2019). This report further recommended that members of the group should be prosecuted for rapes, sexual slavery and other forms of sexual violence (Dutta 2019). There is also the widely reported abduction of 110 school girls in Dapchi (BBC News 2018). Few lost their lives in the process but one of the captives, Leah Sharibu, who was just fourteen years as at the date of the abduction in February 2019 was not released for failure to renounce her faith. She is still in captivity and has been reported to have been delivered of a baby (Eyoboka, 2020).

The exact number of women and girls including boys that have been raped or sexually abused in Nigeria with respect to the on-going conflict is unknown but some girls and women who have been fortunate to escape from the grip of the sect or rescued by the Nigerian Army gave some insights into the horrors of life in the camps run by the sect. Presented below are a few of such gory details of sexual abuses by the sect against their victims.

Asabe Aliyu, a 23 year old mother of four was found vomiting blood at the time of her rescue from the Sambisa forest by men of the Nigerian Army in 2015. Reporting her experience, she stated that the terrorists took turns to have 
sex with her on a daily basis and she ended up being pregnant and was forced into an unwanted marriage (Daily Beast, 2017). Another lady who escaped from Boko Haram abduction a few days after she was kidnapped reported that she was raped 15 times a day by 15 men throughout the period she was with the insurgents before she was able to escape from their den (Akukwe, 2019). These are just excerpt of the sects' devastating use of rape as a method of terrorism.

There has been an increase in the reported incidents of sexual violence in the northeast Nigeria. A total 997 cases were reported in 2017 alone and 664 in the year 2016 (United Nations, 2018). These cases include rape, sexual slavery and forced marriages by Boko Haram insurgents (Campbell, 2019). It is important to note that those who return after abduction face the challenge of being stigmatized. Those who return pregnant or with children conceived through rape are usually rejected or forced to choose between their babies and their families (Ibid).

Justice Louis Brandeis once remarked that 'sunlight is said to be the best of disinfectant' (Ibid). Once, we have acknowledged Boko Haram's sexual and gender based crimes, providing justice to survivors and victims' is a necessary step but unfortunately to date no single member of Boko Haram has been prosecuted for sexual violence. As President Buhari tinkers with the idea of granting amnesty to repentant members of the sect, justice requires accountability for their crimes including those of sexual violence which contravenes the provisions of the Constitution and other relevant international and regional laws. The government should also note that amnesty can only be granted for participation in armed conflict and not for committing crimes (Ibid).

The abductions and rapes by the sect are not only criminal acts which constitutes a criminal offence but also a violation of the rights of the victims as stipulated and guaranteed under chapter four of the Constitution of the Federal Republic of Nigeria, 1999 (as amended) which contains human rights provisions.

Section 33 of the Constitution provides that:

Every individual is entitled to respect for the dignity of his person, and accordingly-

1) no person shall be subject to torture or to inhuman or degrading treatment

2) no person shall be held in slavery or servitude and

3) no person shall be required to perform forced or compulsory labour.

Going by this provision, the Constitution did not specifically mention sexual violence but sexual violence can readily be considered as an extreme form of violation of human dignity under this provision when it is considered that protection of dignity and prohibition of inhumane and degrading treatment can accommodate sexual violence by jurisprudential interpretation thereby making it a residual clause as noted above. In that case however, the members of the Boko Haram sect have violated the law and should be held accountable. As earlier noted in the paper, not a single member of the sect has been charged or prosecuted for sexual violence and not a single member of the Nigerian Armed Force 
or Civilian Joint Task Force has been prosecuted (Amnesty International, 2019). It is not also on record that these crimes have been investigated by any authority in Nigeria.

\section{Challenges of Prosecuting Sexual Violence in Armed Conflict Situation in Nigeria}

The creation of the International Criminal Court (ICC) has greatly increased the ability and the chances of the international community to prosecute the crime of sexual violence. The attention that the crime of sexual violence has received with the adoption of Resolution 1325 in year 2000 from the United Nations Security Council has increased (Seelinger, 2014). With the increased attention, it is sad to note that only few perpetrators have been tried by the international tribunals for sexual violence either as a war crime, crime against humanity or genocide and fewer were found guilty and convicted. This trend is informed by the fact that collection of evidence has been challenging for the international tribunals due to cultural and political dispositions and ideologies, distance and effluxion of time. Again, international tribunals target those they believe to bear the greatest degree of responsibility for these crimes and little attention is paid to those who may also have participated at the middle or low levels (Ibid).

National courts or legal systems play a very crucial role in ensuring accountability for most of the sexual offences committed in times of armed conflict. Where a State has domesticated the Rome Statute of the ICC, the national courts would not only have their normal jurisdiction to hear and determine general cases of sexual and gender based violence which do not occur in times of armed conflict but can also hear and determine cases of sexual violence that took place in times of conflict which may either be a war crime, crime against humanity or genocide. It is important to observe that addressing accountability issue where it is impossible for the international tribunals to do so would require that the capacity of the national courts to respond to cases of sexual violence in armed conflict be determined to enable it take its position as a court of first instance as the right to investigate crimes committed in times of armed conflict rests with the national courts in pursuance of the complementarity rule as provided in Article 17 Rome Statute of the ICC. The ICC is a complementary Court; national courts remain the basic fora for the prosecution of sexual violence for the reasons below.

First, by the complementarity principle enunciated under the Rome Statute, a State Party to the Rome Statute remain responsible for investigating and prosecuting serious international crimes committed on its territory or by its nationals. ICC will only interfere where the States are unwilling and genuinely unable to do so as stipulated in the $10^{\text {th }}$ Preambular paragraph, Article 1 and 17(1) Rome Statute.

Second, effective investigation and prosecution is still very essential even in the face of ICC's intervention. Third, many crimes of sexual violence in domestic 
law such as rape, domestic violence, sexual harassment, trafficking, gang rape and incest do not come under the jurisdiction of the ICC. The jurisdiction of the ICC covers war crimes, crimes against humanity, genocide and crimes of aggression as contained in Articles 5 - 8 of the Rome-Statute For Nigeria to exercise jurisdiction over these international crimes the following must be resolved. These challenges are legal as well as and non-legal but they are all inter related and inter dependent.

\subsection{Non-Domestication of International Treaties on Sexual Violence}

The non-domestication of international treaties on the subject under discussion will make it practically impossible for Nigeria to prosecute the crimes of sexual violence in times of armed conflict. It is important to note that Nigerian Penal Laws (the Criminal Code and the Penal Code) may not be amended or reviewed until the treaties recognizing sexual violence as crimes of international magnitude are domesticated. On the one hand, the Constitution in section 34 recognizes the rights of citizens not to be treated inhumanely and on the other hand, the same Constitution forbids the implementation or enforcement of any treaty which the government has entered into with any other State(s) except it has gone through the process of domestication by the National Assembly as provided for under section 12 of the Constitution.

Consequently, Nigeria has ratified the Additional Protocols to the Geneva Conventions, the Rome Statute, the Convention on the Elimination of All Forms of Discrimination Against Women (CEDAW), the Protocol to the African Charter on Human and Peoples' Rights on the Rights of Women in Africa (the Maputo Protocol) but is yet to domesticate any of them and until the Rome Statute and other relevant international treaties are domesticated, Nigerian Courts may not be able to prosecute because the extant penal codes have not been reviewed.

This creates a huge gap in the accountability processes as the lack of the necessary laws for prosecution may be the reason for the prevalence of the crime of sexual violence in armed conflicts.

\subsection{Inadequacy of the Criminal and Penal Codes}

For Nigeria to prosecute sexual violence in times of armed conflict, the national laws on sexual violence must be reformed. Currently, there is no domestic legislation that criminalizes sexual violence in times of armed conflict.

The Nigerian Penal Codes which are the Criminal Code Act and Penal Code are applicable in the Southern and Northern States respectively. They are peace time legislations. These laws need to be reviewed so they can reflect the new international norms against sexual violence. For instance, section 1 of the Violence against Persons Prohibition Act (VAPPA) enacted in 2015 gives a broader definition of the crime of rape and includes males and females but the application of this law is limited to the Federal Capital Territory (FCT) Abuja. The need to 
reform the laws cannot be overemphasized. This is because sexual violence takes many forms involving so many victims, with perpetrators operating in organizational forms as disparate as State armies, Para-Military groups, non-State actors and even the police in peace time as earlier noted and time of extreme violence.

The form, scale and context of sexual violence determine to a large extent how it is conceptualized and prosecuted by national courts. Due to the pervasive nature of sexual violence during armed conflicts, it is usually prosecuted as international crimes since they are crimes against humanity, war crime and genocide where the sexual violence is of an unprecedented nature while domestic charges of sexual violence are used to prosecute peacetime or threshold forms of sexual violence such as rape, incest or sexual harassment.

It is interesting to note that national courts can prosecute both international and domestic forms of sexual violence if the national Penal Codes have been amended to recognize war crimes, crimes against humanity and genocide. This amendment has not been done in Nigeria.

\subsection{Lack of Access and Confidence in the Legal System by the Survivors}

In Nigeria, most citizens do not have confidence in the judicial process and may never resort to the courts for the resolution of any dispute or to seek redress for any wrong that they have suffered in peace time and becomes more difficult in periods of conflict. Again, where the victims live in remote villages, physical access to the legal system may be difficult. If a victim does not live near a police station or a court, the need to travel to report a crime can be a huge obstacle. Even where the victim lives near a police station, most of the police officers if not all will not be on ground to receive complaints. The task of investigating and documenting sexual violence during armed conflict can be enormous especially if armed actors are involved. Most often than not, one would discover that the police have a gender bias when cases of sexual violence occur. Aside these, the police station may have been targeted and destroyed making it difficult for the police to function optimally.

The victims may not have access to transportation and may not know where to go. The victims may not also have the resources to pursue a case. In Nigeria, the cost of litigation is quite prohibitive and the Legal Aid Council which is statutorily charged with providing free legal services for the indigent may be handle the matter negligently as the Prosecutor will not apply himself to the processes since he would not be paid by the victim. In addition to this, the unduly long period that it takes for criminal cases to be resolved may also work as a deterrent to victims. The insensitive attitude of the police may also deter women form reporting, and lack of victims' protection hinders effective prosecution.

\subsection{Lack of Specialized Courts and Trained Personnel for Conflict Related Sexual Offences}

In Nigeria, to effectively prosecute the crime of sexual violence in armed conflict, 
there is the need to establish specialized courts and agencies to investigate and prosecute sexual offences of this nature and magnitude. Due to the fact that conflict based sexual offence are international crimes, the Judges and other personnel of the court and agency especially the Prosecutors must be well versed in International Criminal Law procedures. They must have a good knowledge about the elements of crime if they want to secure convictions. For instance, in domestic crimes of sexual violence, the lawyers duty is to prove that the charged acts of sexual acts occurred and the direct perpetrator's intent to commit the crime. But where it involves crimes of international character such as sexual violence in armed conflict, the Prosecutor must not only prove the charged acts of sexual violence occurred but must link those acts to a particular context. For example, the acts of sexual violence must be shown to have been committed against a particular group with an intent to destroy it (genocide) in a widespread or systematic manner (if charged as crime against humanity) or during an armed conflict (if charged as a war crime (Aranburu, 2010). This requires proper and diligent investigation. Nigeria cannot do this currently until the required personnel, training and infrastructure is put in place.

\subsection{The Nature of Criminal Responsibility in Sexual Violence Offences}

A direct effect of sexual violence in times of armed conflict is the fact that the perpetrator may not be the one standing trial. In a domestic setting, the physical perpetrator faces charges but with international crimes, the one bearing the responsibility may not have committed the crime, he is standing trial as a commander where he failed to do the needful by preventing the men under his control and authority from committing sexual violence and for his failure to punish the perpetrators. Where the defendant is not the perpetrator, the Prosecutor must link him to those acts through other forms of legal responsibility such as aiding and abetting, joint criminal enterprise or command/superior responsibility (Sellers, 2004). These are not required for domestic crimes of sexual violence. Identifying the perpetrators and their commanders in Nigeria has proven to be a difficult task.

Prosecution of sexual violence in times of armed conflict requires different legal requirements and forms of responsibility. International and domestic cases involve different kind of evidence, investigation and prosecution strategies and victims of international sexual violence must be protected.

\subsection{Unwillingness and Inability on the Part of the Survivors to Report}

The unwillingness and inability of the survivors to come forward and report the crimes is also a challenge to the investigation and prosecution of perpetrators. It has been noted by women's rights advocates and the police that the major reason for survivors' unwillingness to seek justice through the formal channels is because they were both not emotionally and psychologically able to 
do so (Seelinger, 2014). Bearing in mind that there is a near absence of psychological support in times of active conflict for survivors to depend on, the situation of the victims generally becomes difficult to address. Where there are no victims, there would be no investigation and prosecution and accountability mechanism will fail.

Women who survive sexual violence in times of armed conflict face a lot of challenges. Women are seen in most parts of the world including Nigeria as keepers of the family, virtue and female modesty which is enshrined in tradition. A woman may suffer if she reports the crime. She may lose her status in her community or her husband may leave her if she is a married woman. She may even lose her life. In cultures where female sexuality is a taboo like Nigeria, the victims will find it difficult if not impossible to discuss their plight with male authorities. Victims of sexual violence have come to accept their fate as a fact of life. In such circumstance victims of sexual violence are pressured not to report same to authorities (Kelly, 2015).

In some climes, it is considered that acts of sexual violence are not necessarily attacks against the woman's physical integrity, but against her family honour and rights also works as a strong constraint to the reporting and prosecution of crimes of sexual violence. According to the first Special Rapporteur on violence against women, its Causes and Consequences:

By using the honour paradigm, linked as it is to concepts of chastity, purity and virginity, stereotypical concepts of feminity have been formally enshrined in humanitarian law ... When rape is perceived as a crime against honour or morality, shame commonly ensues for the victim, who is often viewed by the community as "dirty" or "spoiled". Consequently, many women will neither report nor discuss the violence that has been perpetrated against them (UN Special Rapporteur, 1998).

\subsection{Stockholm Syndrome}

Another important constraint in prosecuting sexual violence in Nigeria, which is also closely tied to unwillingness of victims to report the crime, is the "Stockholm syndrome." This occurs when victims develop an emotional bond with their abductors during the period of their captivity. The syndrome has also been explained to mean a "psychological response wherein a captive begins to identify closely with his or her captors as well as with their agenda and demands" (Lambert, 2020). There are four key characteristics that have been identified with this syndrome among which is the refusal by hostages to cooperate with the Police as well as other government authorities when it comes to holding perpetrators of abuse or kidnapping accountable (Stines, 2019).

In Nigeria, there are several incidents of abductors taking their victims as "bush wives" with the victims refusing to return home even when freed. There are also reported cases of freed victims returning to their abductors shortly after they regain their freedom. In all of this, the prosecution of the abductors is made 
more difficult in view of the unwillingness of the victims who are now assailed with Stockholm syndrome to come forward to give evidence against their abductors. This is therefore, a setback to prosecution.

\subsection{Stigmatization}

Often, victims of sexual violence are stigmatized. Some of these victims are treated as outcasts and blamed for their predicament. Some may respond by inflicting injury on themselves to express their trauma, anger or to block out painful thoughts. The shame, guilt and lack of support affect their self worth (Akpoghome, 2016). Other psychological consequences of sexual violence have been identified to include, depression, anxiety, post-traumatic stress disorder, shock, memory loss and sexual dysfunction (Amnesty International, 2007). A further fall out of sexual violence and the consequent stigmatization is the fact that a girl who has been raped may find it extremely difficult to find a life partner and married women also risk being divorced by their husbands. A further dimension to stigmatization is the fact that victims of sexual violence who have become pregnant as a result of being raped suffer an even deeper rejection by the community as well as economic deprivation (Trurh and Reconciliation Commission of Liberia Diaspora Project, 2009).

\subsection{Lack of Knowledge}

Many Nigerians are not aware of how to protect themselves in times of armed conflict. In addition to this, they are not aware that sexual violence in times of armed conflict constitutes a severe breach of international laws and that it is a different genre of offence that attracts very severe sanctions. For prosecution to happen, citizens must be taught about these crimes and the signs of these crimes. Members of the armed groups also need to be taught and be made to know that sexual offences in times of armed conflict is a crime and that at the end of the hostilities, they would be held accountable for crimes they have committed during the period of the conflict.

\section{Surmounting the Challenges in Prosecution}

To bridge the gap created by the non domestication of relevant treaties that call out and criminalise sexual violence during armed conflict situations, the legislature must be ready to adopt international treaties in this regard which Nigeria has ratified. Such treaties include the Rome Statute, the Convention on the Elimination of all forms of Discrimination Against Women, The Protocol to the African Charter on Human and Peoples' right on the Rights of Women, (Maputo Protocol). Furthermore, the enactment of Child's Right Act (CRA, 2003) and Violence against Person Prohibition Act 2015 in all the States of the Federation is imperative.

The current penal laws in Nigeria as already pointed out are inadequate because they do not recognize or make provision for sexual violence in times of 
armed conflict. There is the need for these laws to be reviewed to accommodate sexual crimes of international nature that happens in times of armed conflict. Without reviewing the laws, the quest for accountability may be a futile journey. Reviewing the laws also means that the law makers should be able to know the differences between the crimes.

Victims/survivors of sexual violence should be given all the help they need and government must be ready to investigate and prosecute sexual offences. Once a perpetrator is charged and convicted; more survivors will be willing to report these crimes. The courts should be made more accessible. Victims must have access to justice. Government should take up the cost of litigation in cases of sexual violence. Courts must not unnecessarily delay the prosecution of these cases by unending adjournment which at the end of the day serves no useful purpose than frustrating the victims.

It is trite that investigation and prosecution of conflict based violence requires a level of specialty, therefore special courts and the required personnel and infrastructure should be put in place. Also, the Nigeria Police Force should create a special unit charged with the responsibility of the care and counseling of victims of sexual violence. This may have the effect of eventually giving the victims the courage to be able to testify about what they suffered in the hands of their abductors. Adequate training must be given to the personnel. If this is done, the confidence of the victims in the judicial process will be re-ignited and victims must be given adequate protection at all times. The issue of knowledge cannot be over-emphasized. There is need to have continuous civil instructions for the citizens in times of peace. The armed groups should be made to include these crimes and their punishments in their codes of conduct. As they read their codes they would also learn about crimes and accountability.

\section{Conclusion}

The cumulative effects of the 2014 Chibok girls' abduction have culminated in Nigeria witnessing a rise in the spate of sexual violence by armed groups and the military. Top on the list is the activities of the Boko Haram insurgents in this regard. Unfortunately, not a single member of an armed group has been held accountable for the crime of sexual violence or any other crime. The reasons for the inability of Nigeria to prosecute sexual violence in times of armed conflict have been articulated and suggestions made to help move the country forward in this direction. The government must strive to ensure that security of lives and property of the citizens is guaranteed, this being the primary purpose of government and also to defend the Constitution which they swore to uphold.

Sexual violence is a deliberate tactics of war and terrorism. It is integral to the strategy of domination and self perpetuation of the armed actors. Book Haram and the other actors have institutionalized the brutalization of women and girls, destroying their communities and waging war on their physical, sexual and reproductive autonomy and rights. This raises serious concerns for the sexual and 
reproductive health of a whole generation of women and girls who have experienced sexual violence in the hands of their captors. Sexual violence, in its destruction of the individual and the pervasive way it undermines peace and development casts a long shadow over our collective community. The Executive, the Judiciary, the Legislature and all stakeholders must rise up to the challenge and tackle the issue of sexual violence in armed conflict situations in Nigeria. The gap in accountability breeds and encourages insecurity in Nigeria.

\section{Conflicts of Interest}

The authors declare no conflicts of interest regarding the publication of this paper.

\section{References}

(1994). The International Criminal Tribunal for Rwanda (ICTR).

(1998). Rome Statute of the International Criminal Court (ICC).

(2001). The International Criminal Tribunal for Yugoslavia (ICTR).

(2004). The Criminal Code Act. Federal Republic of Nigeria, CAP C39, LFN.

(2004). The Penal Code Act. Federal Republic of Nigeria, CAP 53 LFN.

(2007). The Appeal Chamber of the Special Court for Sierra Leone.

(2018). Report of the Secretary General, United Nations on Conflict-Related Sexual Violence.

Akpoghome, T. U. (2016). Analysis of Domestic Legal Framework on Sexual Violence in Nigeria. Journal of Law and Criminal Justice, 4, 17-30.

https://doi.org/10.15640/jlcj.v4n2a3

Akukwe, O. (2019). Chibok Girls, Boko Haram and the Jihad of the Penis. http://www.nigeriabulletin.com

Amnesty International (2007). Cote d'Ivoire: Targeting Women: The Forgotten Victims of the Conflict. Al Index AFR 31/001/2007, March 15.

Amnesty International (2019). Amnesty International Report. http://www.amnesty.org/en/latest/news/2019/04/nigeria-children-and-women-face-vio lence-in-borno-prisons

Aranburu, X. A. (2010). Sexual Violence beyond Reasonable Doubt: Using Pattern Evidence and Analysis for International Crime. Laiden Journal of International Law, 23, 609-627. https://doi.org/10.1017/S0922156510000245

Batchelor, T. (2019). Rape and Sex Slavery: Life as a Girl under Boko Haram Exposed a Year on from Mass Kidnap. https://www/express.co.uk/news/world/57401/Boko-Haran-exposed-year-mass-kidnap

BBC News (2018). Nigeria Dapchi Abductions: School Girls Finally Home.

Bigro, J., \& Vogelstein, R. (2017). Countering Sexual Violence in Conflict. New York: Council on Foreign Relations.

Campbell, J. (2019). Boko Haran's Violence against Women and Girls Demands Justice. https://www.cfr.org/blog.boko-haranms-violenceagainst-women-andgirls-demand-just ice

Daily Beast (2017). Articles Boko Haram Rescued Sex Slaves Tell Their Horror Stories. http://www.thedailybeast.com/articles/2015/05/06/boko-haram-horror-stories-hold-by 
-resecued-girls-in-nigeria.html

Dutta, K. (2019). Boko Haram Has Abducted, Raped and Enslaved 2000 Women in Reign of Terror.

http://www.independent.co.uk/news/world/africa/Boko-Haran-has-abductedraped-an d-enslaved-2000-womeninreignof-terror-10174152.html/

Eyoboka, S. (2020). The Nigerians React to Leah Sharibu's Motherhood Vanguard Newspaper of January 27.

Gaggioli, G. (2014). Sexual Violence in Armed Conflicts: A Violation of International Humanitarian Law and Human Rights Law. International Review of the Red Cross, 96, 503-538. https://doi.org/10.1017/S1816383115000211

Kelly, L. (2015). Promising Practices Addressing Sexual Violence. Paper Presented at the Expert Groups Meeting, UN Division for the Advancement of Women in Collaboration with UN Offices and Crime, Vienna, Austria, May 17-20, 4.

Lambert, L. (2020). Stockholm Syndrome. http://www.britannica.com

Report of the Special Rapporteur on Violence against Women, Its Causes and Consequences, U.N. Economic and Social Council, Commission on Human Right, U.N. Doc. E/CN.4/1997/54 (Jan. 26, 1998) (Prepared by Radhika Coomaraswamy).

Seelinger, K. T. (2014). Domestic Accountability for Sexual Violence: The Potential of Specialised Units in Kenya, Liberia, Sierra Leone and Uganda. International Review of the Red Cross, 96, 539-564. https://doi.org/10.1017/S1816383115000090

Sellers, P. V. (2004). Individuals Liability for Collective Sexual Violence. In K. Karen (Ed.), Gender and Human Rights (pp. 153-194). Oxford: Oxford University Press. https://doi.org/10.1093/acprof:oso/9780199260911.003.0006

Stines, S. (2019). Why Stockholm Syndrome Happens and How to Help. https://www.livescience.com/65817-stockholm-syndrome.html

The Constitution of the Federal Republic of Nigeria 1999 as Amended.

Trurh and Reconciliation Commission of Liberia Diaspora Project (2009). The Advocates for Human Rights, A House with Two Rooms: The Final Report. 